\title{
POLITICALLY CONNECTED BANKS: SOME INDONESIAN EVIDENCE
}

\author{
Bambang Sutopo \\ Universitas Sebelas Maret \\ Irwan Trinugroho* \\ Universitas Sebelas Maret \\ Sylviana Maya Damayanti \\ Institut Teknologi Bandung
}

\begin{abstract}
We investigate the impact of being politically connected on bank performance and cost of funding. We study 89 Indonesian banks over the 2001-2008 period disentangled into politically connected banks which can be state-owned banks and private banks as well as non-politically connected banks. Controlling for bank fundamental factors and time effect, we do find that political connections improve bank performance. Moreover, our results provide evidence that politically connected banks are benefited by getting a lower cost of funding. Finally, our result reveals that political connections are less valuable for foreign banks.
\end{abstract}

Keywords: Political Connections; Performance; Cost of Funding; Foreign Banks; Indonesia.

\section{INTRODUCTION}

The impact of being politically connected firms has been widely discussed in the literature. Wu et al. (2010) explain that based on the resources-based view theory, political connections are a resource that are difficult or costly for other firms to get thus its possession is a source of competitive advantage. Political connections are more useful for firms in which politics is an important determinant of their profitability (Agrawal and Knoeber, 2001). Some also argue that being politically connected are valuable for firms as their connections may provide "privileges" such as prevent them from competition, could create industry barrier to entry, more likely to be bailed out and improve access to resources. On the other side, however, it could also be argued that political connections could be a burden for a firm as the connections may create well-performed firms that dependent on favorable government policies. It thus causes them more susceptible to the political issues, political changes or regulatory reforms.

Access to financing is the main benefit that has been widely studied (Khwaja and Mian, 2005; Fraser et al., 2006; Charumilind et al., 2006; Li et al., 2008; Claessens et al., 2008), as it could be argued that political figures in the firms can use their power to obtain access

*Corresponding author: Faculty of Economics and Business, Universitas Sebelas Maret, Jl. Ir. Sutami 36A, Surakarta 57126, Indonesia. Email: irwan.trinugroho@gmail.com 
of financing, especially bank loan. Other benefits of being politically connected that have been studied in the literature are better performance and higher market value (e.g. Du and Girma, 2010; Goldman et al., 2009) and lower cost of equity capital (Boubakri, 2012). On the other hand, however, the opponents argue that political connections may create wellperformed firms that dependent on favorable government policies. It thus causes them more susceptible to the political changes or regulatory reforms (Leuz and OberholzerGee, 2006). Several empirical studies also show the negative impacts of political connections for firms, such as increasing cost of debt (Bliss and Gul, 2012), risky and can hurt performance (Lux et al., 2012) and increasing audit fees (Gul, 2006; Wahab et al., 2009). ${ }^{1}$

The present paper investigates the impact of being politically connected banks on performance and cost of funding. We focus on banking firms as there are only few papers that have studied political connections in the banking industry (e.g. Carretta, 2012; Polsiri and Jiraporn, 2012; Disli et al., 2013; Prabowo, 2013; Nys et al., 2015). Carretta et al. (2012) focus on the impact of connections on intermediation activities, while Disli et al., (2013) and Nys et al. (2015), based on market discipline and implicit guarantee perspective, highlight the effect of political connections on depositor behaviors especially with regards to shifting of the deposit insurance system from blanket guarantee to limited guarantee system. Similarly, Polsiri and Jiraporn (2012) emphasize on the role of political connections on failure likelihood of banks. Prabowo (2013) examines the moderating effect of political connections in the effect of family ownership on bank performance.

Our paper focuses on the benefits of being politically connected banks, more specifically on cost of funding and ultimately on performance. We argue that politically connected banks are benefited in term of getting lower interest on deposits as they might be perceived as less risky by depositors because the government would most likely rescue them when they face financial distress (Braun and Raddatz, 2010; Nys et al., 2015). Being politically connected might also ease banks to have larger access to fund particularly from government budget and state-owned enterprises projects with a lower interest rate. Moreover, they could also charge a higher interest on loan as they are supposed to have a higher market power which subsequently could improve performance.

Going deeper, we look at the difference effect of political connections of foreign and private banks. Arguably, the value of political connections of foreign banks is less than that of domestic banks. Foreign banks' presence in a developing country is expected to bring favorable economic impacts to the host country as they have better hard information and technology which lead them to perform more efficiently in their business (Claessens et al., 2001; Trinugroho et al., 2014). Therefore, we suppose that being political connections should be less valuable for foreign banks.

We study Indonesian banks for several reasons. First, as revealed by Faccio (2006), political influences in business is more prevalent in the countries with poor governance such as weak law enforcement and corruption. Second, we take advantage of the data on

\footnotetext{
${ }^{1}$ For the literature review of the benefits and disadvantages of being politically-connected firms, see the paper of Nys et al. (2015)
} 
political connections of Indonesian banks which are manually retrieved based on the work of Nys et al (2015).

\section{POLITICAL CONNECTIONS AND PERFORMANCE}

Those from economics and finance have paid attention on what they call "politically connected firms" which are defined as firms having close relationship with whom control the political power (Carretta et al, 2012; Nys et al., 2015) through for example recruiting bureaucrats (and former bureaucrats) or politicians on the board of directors and commissioners. Moreover, the source of political connections could also come from the controlling shareholders. They could be a member of parliament, former bureaucrat, former military, or even a top leader in a political party.

Many papers, mostly come from management scholars, have also studied corporate political strategies or corporate political activities (CPA). Shaffer (1995) provides a review of theoretical perspectives on business political activity, variables that explain patterns of business political activity, research methods used in empirical studies of business political activity and directions for further research. Continuing the work of Shaffer (1995), Hillman et al. (2004) present a comprehensive model of the antecedents of CPA, the types of CPA, the ways to implement CPA and the outcomes of CPA. It is then refined by Lux et al. (2011) who provide a meta-analysis of antecedents and outcomes of CPA. They conclude that CPA is positively related to firm performance and is an important determinant of firm performance. The terms corporate political activity and corporate political connection are slightly different. Corporate political activity refers to an effort to influence or manage political entities (Hillman et al., 2004), whereas corporate political connection is usually embedded or given in a corporation due to the existence of politically connected controlling shareholders or politically connected board members, even though some studies use political connections but their measures are activities (e.g. Claessens et al., 2008).

Political connections are believed to be a valuable resource for many firms especially for private firms (Li et al., 2008) through several ways such as access to finance, sales to government, tax benefits and market power that ultimately could improve their performance. Fisman (2001) shows that market value of the companies connected to Suharto's family in Indonesia are vulnerable to the announcement of Suharto's illness which means that there is a strong association between being politically connected and performance. Likewise, Goldman et al. (2009) show that there is positive abnormal stock return in the announcement of politically connected directors. Wu et al. (2010) reveal that Chinese politically connected private firms enjoy tax benefits that subsequently improve their performance. In an empirical study using Chinese firms, You and Du (2012) show that the value of political connections is contingent to operating performance. Wang et al. (2011) find evidence that top management team with governmental experience contributes to improve performance of private firms. Lux et al. (2012), in overall, conclude that mixing business with politics could be beneficial, even though executives should be careful in practice. Prabowo (2013) argues that political connections might play role as a contingency factor in explaining the performance difference between family- 
controlled and non-family controlled firms. However, no empirical evidence is found for this hypothesis.

Banking is the main financial intermediary channel in Indonesia as the capital market in this country is still relatively underdeveloped (Trinugroho et al., 2014). Moreover, due to the level of financial literacy is relatively still lower, average people do not participate in the capital market. Due to its importance in the country's economy, banking is strongly influenced by some political aspects. For instance, during the damage crisis in 1997/1998, the government had to intervene the banking sector to avoid the collapse of banking industry by injecting capital to a number of large banks and closing some small banks. During the global financial crisis in the late of 2008, a mid-sized bank called Bank Century was also decided to be bailed out. It then became a political issue in the country. Some papers have also revealed that there is political consideration in the banking sector. Nys et al. (2015) find empirical evidence that political connections of banks has more effect after the shifting from full guarantee to limited guarantee deposit insurance system. In the $1997 / 1998$ crisis and shortly after that, there was also a flight to quality of deposits from small banks to large banks due to the later was perceived to be retained by the government (Yudistira, 2002; Hadad et al., 2011)

\section{METHODOLOGY}

We focus to investigate the impact of political connections (POLCON) on performance and cost of funding by studying Indonesian banking firms. Our study relies on data of 89 Indonesian banks over the period of 2001-2008. Finally 545 bank-year observations are included in our sample.

According to the work of Prabowo (2013) and Nys et al. (2015), we categorize politically connected banks as 1) state-owned banks ( $\mathrm{SOB}$ ) and 2) politically connected private banks (PBCON) defined as those controlled by politicians or having at least one politically connected commissioners or directors as a bureaucrat (government officer), or a former bureaucrat, or a parliament member, or a political party member or a former parliament member.

To estimate the impact of political connections on bank performance and cost of funding, we test our hypotheses using a multivariate analysis. The regression models are following:

$$
\begin{aligned}
& P_{E R F_{i, t}}=\alpha_{0}+\alpha_{1} \text { POLCON }_{i, t}+\alpha_{2} \text { DIV }_{i, t}+\alpha_{3} L_{E R N E R_{i, t}}+\alpha_{4} E Q T A_{i, t}+\alpha_{5} \text { LISTED }_{i}+\alpha_{6} F O B_{i} \\
& + \text { YEARS }+\varepsilon_{i, t}
\end{aligned}
$$

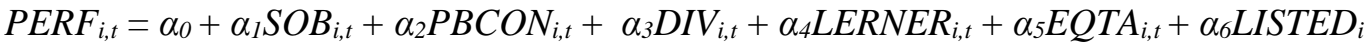

$$
\begin{aligned}
& +\alpha_{7} F O B_{i}+Y E A R S+\varepsilon_{i, t} \\
& \operatorname{COST}_{i, t}=\alpha_{0}+\alpha_{1} \text { POLCON }_{i, t}+\alpha_{2} \text { DIV }_{i, t}+\alpha_{3} \text { LERNER }_{i, t}+\alpha_{4} E \text { OTA }_{i, t}+\alpha_{5} \operatorname{LISTED}_{i}+\alpha_{6} \text { FOB }_{i} \\
& +Y E A R S+\varepsilon_{i, t}
\end{aligned}
$$




$$
\begin{aligned}
& \operatorname{COST}_{i, t}=\alpha_{0}+\alpha_{1} \operatorname{SOB}_{i, t}+\alpha_{2} \text { PBCON }_{i, t}+\alpha_{3} \text { DIV }_{i, t}+\alpha_{4} \text { LERNER }_{i, t}+\alpha_{5} \text { EQTA }_{i, t}+\alpha_{6} \text { LISTED }_{i} \\
& +\alpha_{7} F O B_{i}+Y E A R S+\varepsilon_{i, t}
\end{aligned}
$$

\begin{tabular}{|c|c|}
\hline RF & $\begin{array}{l}\text { g performance which is measured by return on assets (ROA) } \\
\text { n on equity (ROE) }\end{array}$ \\
\hline OST & by interest paid on deposits \\
\hline $\mathrm{ON}$ & $\begin{array}{l}\text { variable taking value of } 1 \text { for politically connected banks and } \\
\text { e }\end{array}$ \\
\hline DB & 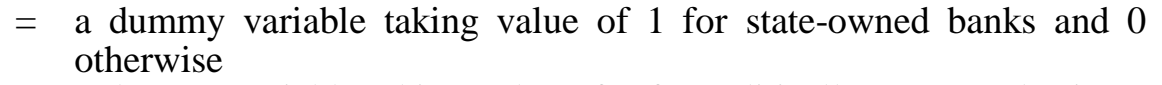 \\
\hline & $=$ a dummy variable taking value of 1 for politically connected priva \\
\hline
\end{tabular}

where:

We take into account some control variables as follows:

DIV is the diversification index measured according to the method developed by Elsas et al. (2010) which is also employed by Prabowo (2013) and Trinugroho et al. (2014); LERNER is the Lerner index as a proxy of banking competition measured based on the method used by Koetter et al. (2012) and Trinugroho et al. (2014). Basically the Lerner Index is the difference between price and marginal cost. The higher the difference it could be considered the higher the market power; EQTA is the ratio of equity to total assets following the work of Prabowo (2013), Trinugroho et al. (2014) and Nys et al. (2015); LISTED is a dummy variable taking value of 1 for publicly traded banks and 0 otherwise; and FOB is a dummy variable taking value of 1 for foreign banks and 0 otherwise.

To test the difference effect of political connections for domestic and foreign banks, we create an interaction variable (PBCON*FOB) between PBCON (politically connected private banks) and FOB (foreign banks). We suppose that the coefficient of interaction variable should be negative for bank performance which means that the effect of political connections on performance is lower for foreign banks. Moreover, it is supposed that the coefficient of interaction variable would be positive for cost of funding which means that political connections of private domestic banks could reduce more cost of funding than that of politically connected foreign banks.

$$
\begin{aligned}
& \text { PERF }_{i, t}=\alpha_{0}+\alpha_{1} \operatorname{SOB}_{i, t}+\alpha_{2} \text { PBCON }_{i, t}+\alpha_{3} \text { PBCON }^{*} F O B_{i, t}+\alpha_{4} D_{1} V_{i, t}+\alpha_{5} \text { LERNER }_{i, t}+ \\
& \alpha_{6} E Q T A_{i, t}+\alpha_{7} L I S T E D_{i}+\alpha_{8} F O B_{i}+Y E A R S+\varepsilon_{i, t} \\
& \operatorname{COST}_{i, t}=\alpha_{0}+\alpha_{1} \operatorname{SOB}_{i, t}+\alpha_{2} \text { PBCON }_{i, t}+\alpha_{3} \text { PBCON }^{*} F O B_{i, t}+\alpha_{4} \text { DIV }_{i, t}+\alpha_{5} \text { LERNER }_{i, t}+ \\
& \alpha_{6} E Q T A_{i, t}+\alpha_{7} L I S T E D_{i}+\alpha_{8} F O B_{i}+Y E A R S+\varepsilon_{i, t}
\end{aligned}
$$

\section{EMPIRICAL RESULTS}

We stress our study to investigate the impact of political connections (POLCON) on performance and cost of funding by studying Indonesian banking firms. We collect data of 89 banks over 2001-2008 period resulting in 545 bank-year observations. During such 

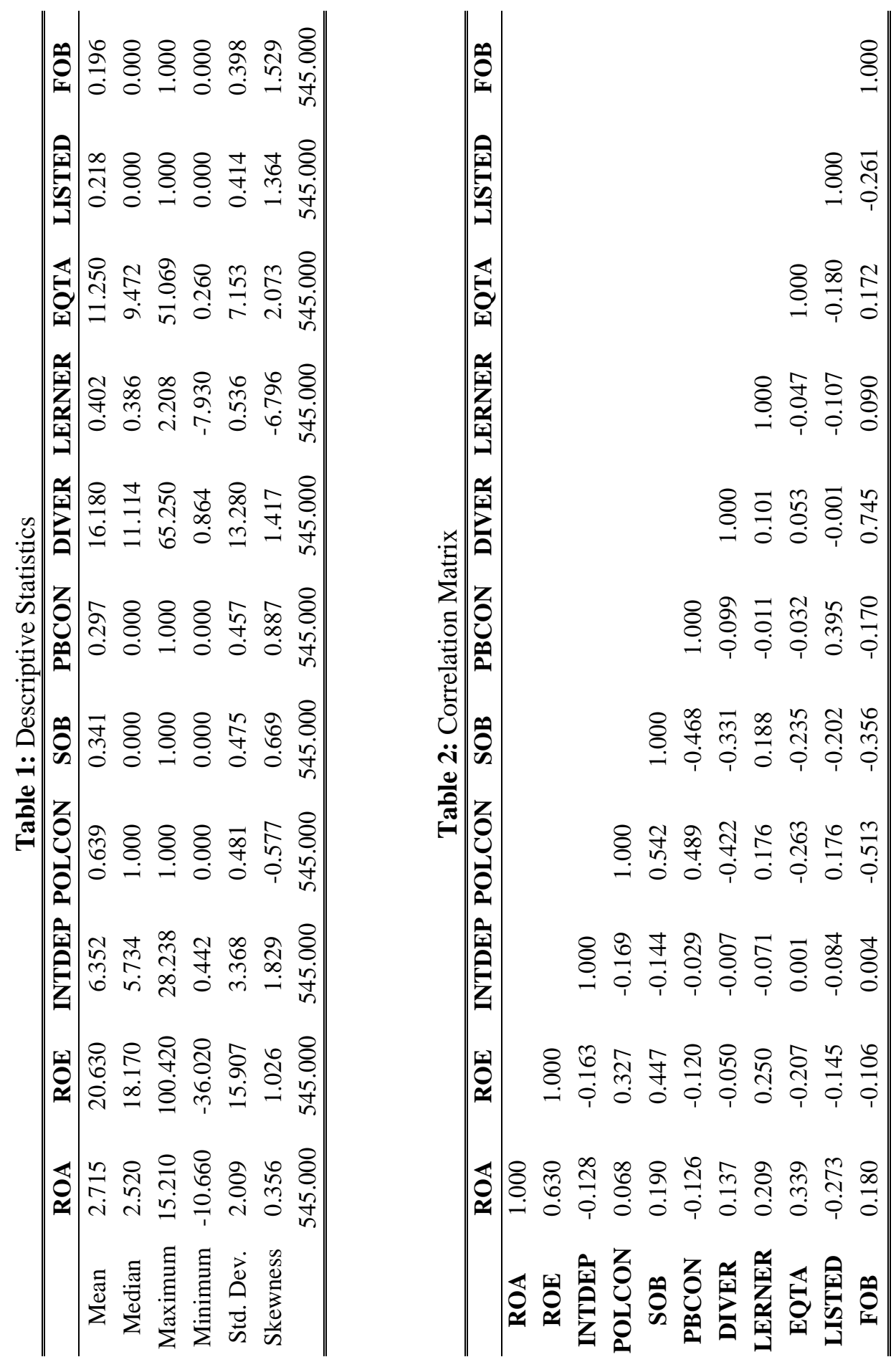


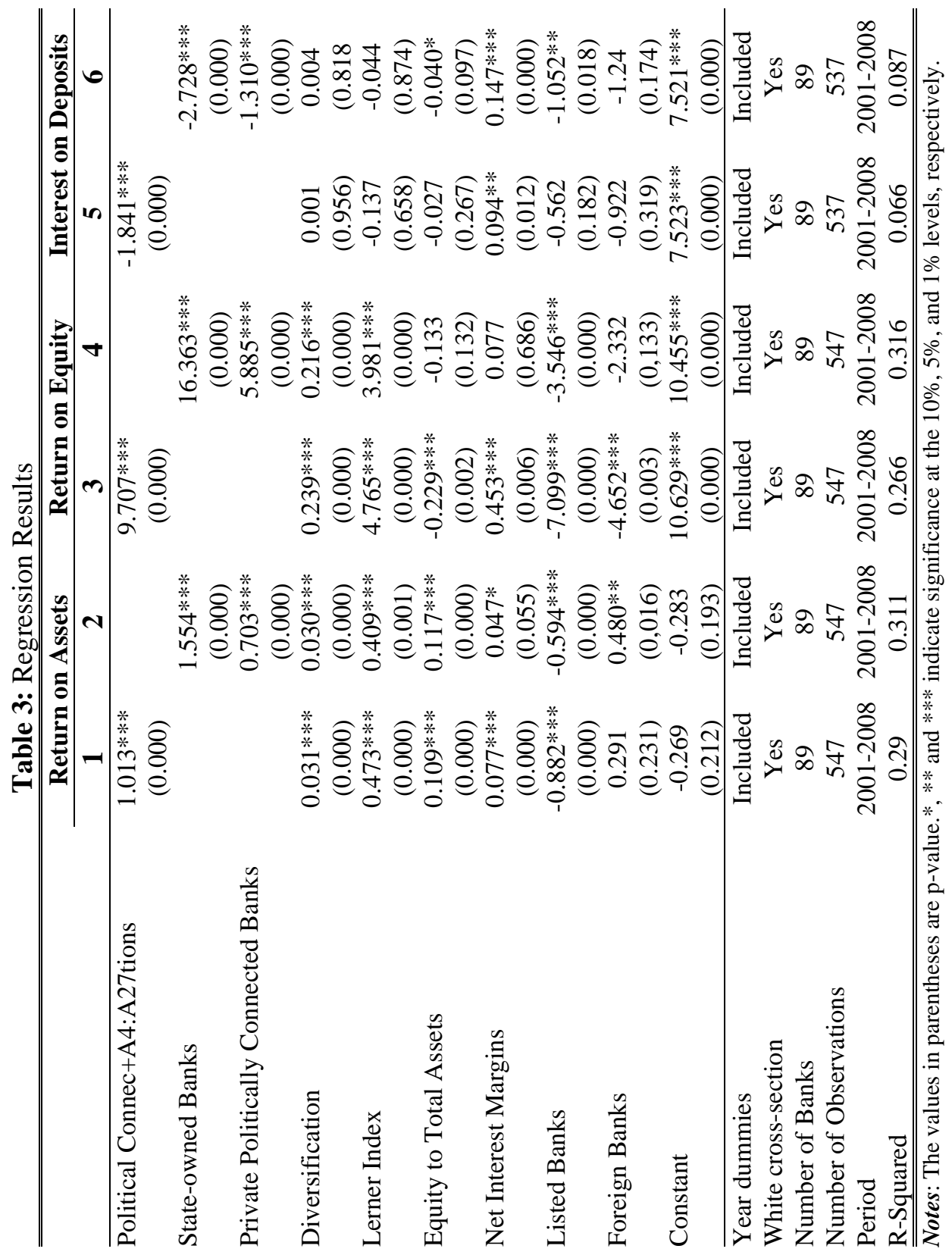


period, the Indonesian banking industry was recovered after the 1997/1998 terrible financial crisis (Trinugroho et al., 2014). Even though the institutional reforms have transformed the country to be more democratized and decentralized (Henderson and Kuncoro, 2011), political connections still play roles in banking (Nys et al., 2015). We proxy political connections using politically connected banks (POLCON). Moreover, we breakdown this variable into: state-owned banks (SOB) and politically connected private banks (PBCON). To estimate the empirical models, we run OLS regressions. We include a number of control variables which are bank diversification index, Lerner index, the ratio of equity to total assets, net interest margins, listed banks, foreign banks and time effect (year dummies).

Table 1 presents the descriptive of statistics of variables. $63.9 \%$ of observations are politically connected banks consisting of $34.1 \%$ state-owned banks (SOB) which are directly connected to the government and $29.7 \%$ politically connected private banks (PBCON). As shown in Table 1, the mean (median) of return on assets (ROA) is $2.715 \%$ $(2.52 \%)$, while the average (median) of return on equity (ROE) is $20.63 \%(18.17 \%)$. The ratio of interest expense to total deposits (INTDEP) has mean (median) of $6.352 \%$ $(5.734 \%)$.

Table 2 exhibits the correlation matrix of variables. As expected, politically connected banks are positively correlated with performance and negatively associated with cost of funding. Similar correlation signs are also found for state-owned banks. Surprisingly, politically connected banks are negatively correlated with bank performance.

As shown in table 3, our results provide evidence that political connections either state or private connected banks positively affect bank performance which is measured by return on assets (ROA) and return on equity (ROE). It confirms our first hypothesis that politically connected banks have a higher performance than those non-politically connected. We suppose that the higher performance of politically connected banks is resulted from their high market power enabling them to charge a higher rate on loan. Moreover, those banks might be benefited from some privileges that they might have. For example, political connections of those banks can help them to obtain deposits from government budget or state-owned enterprises.

We also find that the benefit of being politically connected banks is lowering the cost of funding, measured by the implicit interest rate on deposits (INTDEP). It is argued that politically private banks are perceived as less risky as they might have some special support (privilege) if they encounter financial problem. Our empirical results, as shown in table 3, confirm this hypothesis. Our proxies of political connections (POLCON, SOB, and $\mathrm{PBCON}$ ) are negatively correlated with interest on deposits. It implies that politically connected banks are benefited by their connections to obtain lower cost of funding.

Our additional test on the difference effect of political connections between domestic and foreign banks shows that being politically connections is more valuable for domestic private banks than for foreign banks. Table 4 shows that the interaction variable between politically connected private banks and foreign banks (PBCON*FOB) is negative and significant on return on assets (ROA) and return on equity (ROE). However, we do not 
find evidence that there is a difference effect of political connections on cost of funding between domestic and foreign banks.

Table 4: Regression Results of Interaction Variable

\begin{tabular}{lccc}
\hline \hline & ROA & ROE & INTDEP \\
\hline State-owned Banks & $1.724^{* * *}$ & $17.605^{* * *}$ & $-2.658^{* * *}$ \\
& $(0.000)$ & $(0.000)$ & $(0.000)$ \\
Private Politically Connected Banks (PBCON) & $0.955^{* * *}$ & $7.720^{* * *}$ & $-1.205^{* * *}$ \\
& $(0.000)$ & $(0.000)$ & $(0.000)$ \\
PBCON*FOB & $-1.314^{* * *}$ & $-9.568^{* * *}$ & -0.531 \\
& $(0.002)$ & $(0.000)$ & $(0.461)$ \\
Diversification & $0.028^{* * *}$ & $0.199^{* * *}$ & 0.004 \\
& $(0.000)$ & $(0.000)$ & $(0.866)$ \\
Lerner Index & $0.404^{* * *}$ & $3.942^{* * *}$ & -0.047 \\
& $(0.001)$ & $(0.000)$ & $(0.864)$ \\
Equity to Total Assets & $0.122^{* * *}$ & -0.098 & -0.038 \\
& $(0.000)$ & $(0.297)$ & $(0.136)$ \\
Net Interest Margins & 0.039 & 0.018 & $0.144^{* * *}$ \\
& $(0.120)$ & $(0.923)$ & $(0.000)$ \\
Listed Banks & $-0.623^{* * *}$ & $-3.753^{* * *}$ & $-1.066^{* *}$ \\
& $(0.000)$ & $(0.000)$ & $(0.016)$ \\
Foreign Banks (FOB) & $0.792^{* * *}$ & -0.062 & -1.107 \\
& $(0,001)$ & $(0,973)$ & $(0.277)$ \\
Constant & $-0.392^{*}$ & $9.665^{* * *}$ & $7.479^{* * *}$ \\
& $(0.069)$ & $(0.000)$ & $(0.000)$ \\
\hline Year dummies & Included & Included & Included \\
White cross-section & Yes & Yes & Yes \\
Number of Banks & 89 & 89 & 89 \\
Number of Observations & 547 & 547 & 537 \\
Period & $2001-2008$ & $2001-2008$ & $2001-2008$ \\
R-Squared & 0.319 & 0.322 & 0.087 \\
\hline \hline
\end{tabular}

Notes: The values in parentheses are p-value. $*, * *$ and $* * *$ indicate significance at the $10 \%, 5 \%$, and $1 \%$ levels, respectively.

Overall, our findings support hypothesis that political connections improve bank accounting performance. Interestingly, this evidence is confirmed by the other finding that politically connected banks have lower cost of funding than that of non-politically connected banks. It means that the higher performance of politically connected banks is driven by lower cost of funding which ultimately could lead to higher interest margins. Moreover, our results on the difference effect of political connections between foreign and private banks confirm our hypothesis. These kinds of connections are less beneficial for foreign banks as they have another source of competitive advantage to participate in emerging markets. 


\subsection{Robustness Checks}

We do some robustness checks to ensure that our results are consistent and robust. First, instead of including time-fixed effect in the model, we control for some macroeconomics variables which are inflation and cycle GDP per capita following the study of Nys et al. (2015). Our results remain unchanged. Second, as employed by Nys et al. (2015), we run the estimations using 3SLS to enable us take into account individual fixed-effect. With regard to our political connections variables, the results are consistent.

\section{CONCLUSION}

We study the impact of political connections on bank performance and cost of funding. Being politically connected could be beneficial for banks as those banks might have some privilege especially on access to finance. First, our empirical results find evidence that political connections improve bank performance. It could be argued that being politically connected might ease banks to have larger access to fund. Moreover, their market power helps them to charge a higher rate on loan. Second, we find that politically connected banks have a lower cost of funding than that of non-politically connected banks. Arguably, politically connected banks are benefited in term of getting lower interest on deposits as they might be perceived as less risky by depositors because the government would most likely bail them out when they face financial distress. Third, our result reveals that being politically connections is more valuable for domestic private banks than for foreign banks.

\section{REFERENCES}

Agrawal, A., \& Knoeber, C. R. (2001). Do Some Outside Directors Play a Political Role? Do Some Outside Directors Play a Political Role? Journal of Law and Economics, 44(1), 179-198.

Bliss, M. A., \& Gul., F. A. (2012). Political connection and cost of debt: Some Malaysian evidence. Journal of Banking \& Finance, 36(5), 1520-1527.

Boubakri, N., Guedhami, O., Mishra, D., \& Saffar, W. (2012). Political Connections and the Cost of Equity Capital. Journal of Corporate Finance, 18(3), 541-559.

Braun, M., \& Raddatz, C. (2010). Banking on Politics: When Former High-ranking Politicians Become Bank Directors. The World Bank Economic Review, 24(2), 234-279.

Carretta, A., Farina, V., Gon, A., \& Parisi, A. (2012). Politicians “on board”! Do political connections affect banking activities in Italy? European Management Review, 9(2), 75-83.

Charumilind, C., Kali, R., \& Wiwattanakantang, Y. (2006). Connected Lending: Thailand before the Financial Crisis. Journal of Business, 79(1), 181-217.

Claessens, S., Feijen, L., \& Schmukler, L. (2008). Political connections and preferential access to finance: The role of campaign contributions. Journal of Financial Economics, 88(3), 554-580

Claessens, S., Kunt, D., \& Huizinga, H. (2001). How does foreign entry affect domestic banking markets? Journal of Banking \& Finance, 25(5), 891-911.

Disli, M., Schoors, K., \& Meir, J. (2013). Political connections and depositor discipline. Journal of Financial Stability, 9(4), 804-819. 
Du, J., \& Girma, S. (2010). Red Capitalists: Political Connections and Firm Performance in China. Kyklos, 63(4), 530-545.

Elsas, R., Hackethal, A., \& Holzhäuser, M. (2010). The anatomy of bank diversification. Journal of Banking \& Finance, 34(6), 1274-1287.

Faccio, M. (2006). Politically-connected firms. American Economic Review, 96(1), 369-386.

Fisman, R. (2001). Estimating the value of political connections. American Economic Review, 91(4), 1095-1102.

Fraser, D., Zhang, H., \& Derashid, C. (2006). Capital structure and political patronage: The case of Malaysia. Journal of Banking \& Finance, 30(4), 1291-1308.

Goldman. E., Rocholl, J., So, J. (2009). Do politically connected boards affect firm value? Review of Financial Studies, 22(6), 2331-2360.

Gul, F. A. (2006). Auditors' Response to Political Connections and Cronyism in Malaysia. Journal of Accounting Research, 44(5), 931-963.

Hadad, M. D., Agusman, A., Monroe, G. S., Gasbarro, D., \& Zumwalt, J. K. (2011). Market discipline, financial crisis and regulatory changes: Evidence from Indonesian banks. Journal of Banking and Finance, 35(6), 1552-1562.

Henderson, J. V., \& Kuncoro, A. (2011). Corruption and local democratization in Indonesia: The role of Islamic parties. Journal of Development Economics, 94(2), 164-180.

Hillman, A. J., Keim, G. D., \& Schuler, D. (2004). Corporate Political Activity: A Review and Research Agenda. Journal of Management, 30(6), 837-857.

Khwaja, A. I., \& Mian, A. (2005). Do lenders favor politically connected firms? Rent provision in an emerging financial market. Quarterly Journal of Economics, 120(4), 1371-1411.

Koetter, M., Kolari, J. W., \& Spierdijk, J. (2012). Enjoying the quiet life under deregulation? Evidence from adjusted lerner indices for U.S. banks. Review of Economics and Statistics, 94(2), 462-480.

Leuz, C., \& Oberholzer-Gee, F. (2006). Political relationships, global financing, and corporate transparency: Evidence from Indonesia. Journal of Financial Economics, $81(2), 411-439$

Li, H., Meng, L., Wang, Q., \& Zhou, L. A. (2008). Political connections, financing and firm performance: Evidence from Chinese private firms. Journal of Development Economics, 87(2), 283-299.

Lux, S., Crook, T. L., \& Leap, T. (2012). Corporate political activity: The good, the bad, and the ugly. Business Horizons, 55(3), 307-312.

Lux, S., Crook, T. R., \& Woehr, D. J. (2011). Mixing Business with Politics: A MetaAnalysis of the Antecedents and Outcomes of Corporate Political Activity. Journal of Management, 37(1), 223-247.

Nys, E., Tarazi, A., \& Trinugroho, I. (2015). Political connections, bank deposits, and formal deposit insurance. Journal of Financial Stability, 19, 83-104.

Polsiri, P., \& Jiraporn, P. (2012). Political connections, ownership structure, and financial institution failure. Journal of Multinational Financial Management, 22(1-2), 39-53.

Prabowo, M. A. (2013). Performance of family-controlled firms: Do political connections matter? Jurnal Akuntansi \& Auditing Indonesia, 17(2), 115-122.

Shaffer, B. (1995). Firm-level responses to government regulation: Theoretical and research approaches. Journal of Management, 21(3), 495-514. 
Trinugroho, I., Agusman, A., \& Tarazi, A. (2014). Why have bank interest margins been so high in Indonesia since the 1997/ 1998 financial crisis? Research in International Business and Finance, 32, 139-158.

Wahab, E.A.A., Zain, M.M., James, K., \& Haron, H. (2009). Institutional investors, political connection and audit quality in Malaysia. Accounting Research Journal, 22(2), 167-195.

Wang, H., Feng, J., Liu, X., \& Zhang, R. (2011). What is the benefit of TMT's governmental experience to private-owned enterprises? Evidence from China. Asia Pacific Journal of Management, 28(3), 555-572.

Wu, W., Wu, C., \& Rui, O.M. (2010). Ownership and the Value of Political Connections: Evidence from China. European Financial Management, 18(4), 695-729.

You, J., \& Du, G. (2012). Are Political Connections a Blessing or a Curse? Evidence from CEO Turnover in China. Corporate Governance: An International Review, 20(2), 179-194.

Yudistira, D. (2002). The Impact of Bank Capital Requirements in Indonesia. EconWPA Working Paper No. 0212002. 